\title{
Extreme droughts drive tropical semi-arid eutrophic reservoirs towards $\mathrm{CO}_{2}$ sub-saturation
}

\author{
Secas extremas direcionam os reservatórios eutróficos do semiárido tropical para a
} subsaturação de $\mathrm{CO}_{2}$

Jurandir Rodrigues de Mendonça Júnior ${ }^{1}$, André Megali Amado², Luciana de Oliveira Vidal², Arthur Mattos ${ }^{1}$ and Vanessa Becker ${ }^{1 *}$

'Programa de Pós-graduação em Engenharia Sanitária, Departamento de Engenharia Civil, Universidade Federal do Rio Grande do Norte - UFRN, Av. Senador Salgado Filho, 3000, Campus Universitário, CEP 59078-970, Natal, RN, Brasil

${ }^{2}$ Departamento de Oceanografia e Limnologia, Universidade Federal do Rio Grande do Norte - UFRN, Praia de Mãe Luiza, Av. Via Costeira Senador Dinarte Medeiros Mariz, s/n, CEP 59014-002, Natal, RN, Brasil

${ }^{3}$ Laboratório de Ciências Ambientais, Centro de Biociências e Biotecnologia, Universidade Estadual do Norte Fluminense - UENF, Av. Alberto Lâmego, 2000, Parque Califórnia, CEP 28013-602, Campos dos Goytacazes, RJ, Brasil

*e-mail: becker.vs@gmail.com

Cite as: Mendonça Júnior, J.R. et al. Extreme droughts drive tropical semi-arid eutrophic reservoirs towards $\mathrm{CO}_{2}$ sub-saturation. Acta Limnologica Brasiliensia, 2018, vol. 30, e101.

Abstract: Aim: This study aimed to evaluate the carbon dioxide $\left(\mathrm{CO}_{2}\right)$ dynamics in tropical semi-arid reservoirs during a prolonged drought period as well as to test if the trophic state affects the $\mathrm{CO}_{2}$ saturation. Methods: This study was performed in four reservoirs located in the tropical semi-arid region in the northeast of Brazil. All samplings were performed between 9 and 12 am using a Van Dorn Bottle. Samples for partial pressure of carbon dioxide $\left(p \mathrm{CO}_{2}\right)$ measurements were taken in the sub-surface as well as samples for total phosphorus and chlorophyll- $a$. Correlation analysis and linear regression were used to detect relations among the calculated $p \mathrm{CO}_{2}$, water volume and chlorophyll- $a$. Results: The water level reduction due to atypical droughts caused chlorophyll- $a$ concentrations to increase, which in turn, led to $\mathrm{CO}_{2}$ reduction in the water. However, $\mathrm{CO}_{2}$ concentrations were very variable and an alternation between $\mathrm{CO}_{2}$ sub-saturation and super-saturation conditions was observed. This paper showed that water volume and chlorophyll- $a$ were important regulators of $\mathrm{CO}_{2}$ in the water, as well as important carbon balance predictors in the tropical semiarid reservoirs. Conclusions: The results of this paper indicate that the eutrophication allied to drastic water level reductions lead to a tendency of autotrophic metabolism of these systems.

Keywords: carbon dioxide partial pressure $\left(p \mathrm{CO}_{2}\right)$; carbon sink; carbon source; eutrophication; reservoirs.

Resumo: Objetivo: Avaliar a dinâmica do dióxido de carbono $\left(\mathrm{CO}_{2}\right)$ em reservatórios tropicais semiáridos durante um período prolongado de seca e testar se o estado trófico afeta a saturação de $\mathrm{CO}_{2}$. Métodos: Este estudo foi realizado em quatro reservatórios localizados no semiárido tropical do Nordeste do Brasil. Todas as amostragens foram realizadas entre as 9 e as 12 horas com a garrafa Van Dorn. Amostras para pressão parcial de dióxido de carbono $\left(p \mathrm{CO}_{2}\right)$ foram tomadas na sub-superfície, assim como para fósforo total e clorofila- $a$. As análises de correlação e regressão linear foram usadas 
para buscar relaçóes entre a $p \mathrm{CO}_{2}$ calculada, o volume de água e a clorofila- $a$. Resultados: A redução do nível de água devido aos eventos de seca fez com que as concentraçóes de clorofila- $a$ aumentassem, o que, por sua vez, provocou a redução do $\mathrm{CO}_{2}$ na água. No entanto, as concentraçóes de $\mathrm{CO}_{2}$ foram muito variáveis e observou-se uma alternância entre as condiçôes de subsaturaçáo de $\mathrm{CO}_{2} \mathrm{e}$ supersaturação. Neste trabalho mostramos que o volume de água e a clorofila- $a$ foram importantes reguladores do $\mathrm{CO}_{2}$ na água e, portanto, são importantes preditores do balanço de carbono nos reservatórios da região semiárida tropical. Conclusóes: Os resultados deste trabalho indicam que a eutrofização aliada a reduçôes drásticas do nível de água levam a uma tendência de metabolismo autotrófico desses sistemas.

Palavras-chave: pressão parcial de dióxido de carbono $\left(\rho \mathrm{CO}_{2}\right)$; sequestro de carbono; fonte de carbono; eutrofização; reservatórios.

\section{Introduction}

Inland aquatic ecosystems play an important role in the Global carbon cycle because they are responsible for processing great amounts of organic matter from terrestrial ecosystems and for emitting carbon dioxide $\left(\mathrm{CO}_{2}\right)$ to the atmosphere (Cole et al., 2007; Tranvik et al., 2009; Raymond et al., 2013). Man-made reservoirs are globally numerous (built for water supply, energy production, recreation, navigation and irrigation) and cause significant changes in the landscape by flooding terrestrial habitats and biomass; they usually have large watersheds which result in great availability of organic matter for decomposition (Rosenberg et al., 2000; St. Louis et al., 2000; Friedl \& Wüest, 2002; Humborg et al., 2002; Roland et al. 2010). These ecosystems are particularly relevant to the global carbon balance because they are responsible for an important fraction of the $\mathrm{CO}_{2}$ emission to the atmosphere from inland waters (Oki \& Kanae, 2006; Barros et al., 2011). Furthermore, most of the $\mathrm{CO}_{2}$ emission (up to $70 \%$ ) through reservoirs occurs in tropical regions (St. Louis et al., 2000).

The global ecosystem metabolism results from the balance between production and decomposition of organic matter (as reviewed in Dodds \& Cole, 2007). When production exceeds decomposition, the ecosystems become sub-saturated in $\mathrm{CO}_{2}$ and they are considered autotrophic; however, when consumption exceeds production (based on accumulated autochthonous and allochthonous organic matter) the ecosystems become super-saturated in $\mathrm{CO}_{2}$, so they are considered heterotrophic. Thus, environmental factors such as nutrients (e.g. nitrogen and phosphorous), light, and organic matter availability play a central role in aquatic metabolism regulation (Dodds \& Cole, 2007). For instance, nutrient input can stimulate phytoplankton primary production and $\mathrm{CO}_{2}$ uptake from the water.

The human population growth has turned eutrophication (primary production increase due to nutrients input to inland ecosystems) into a global issue in the last century (Smith \& Schindler, 2009) and several aquatic ecosystems (freshwater and marine) have been suffering its consequences (Smith et al., 2006). For instance, eutrophication process (nutrient input) has been causing phytoplankton blooms and cyanobacterial dominance in several tropical reservoirs (e.g. Soares et al., 2012; Medeiros et al., 2015). Due to high primary production, it could be expected that tropical eutrophic reservoirs would present autotrophic metabolism (Finlay et al., 2009; Lazzarino et al., 2009; Pacheco et al., 2013). However, a recent study demonstrated $\mathrm{CO}_{2}$ supersaturation in 5 tropical eutrophic reservoirs (Roland et al., 2010). In addition, there is rising evidence that the sediment metabolism can play important roles in the carbon balance, either as sink or source of carbon to the water and atmosphere (e.g. Cardoso et al., 2013; Forbes et al., 2012; Mendonça et al., 2012). Thus, it is not yet clear what the role of the tropical reservoirs in the carbon cycle is.

The tropical semi-arid region in Brazil presents high temperatures year-round, long periods of drought and torrential rains in a short time. This region is dominated by reservoirs that have been turning eutrophic due to nutrient inputs from land and concentration of the nutrients in the water because of high evaporation rates and long hydraulic retention times (Chellappa et al., 2009; Barbosa et al., 2012; Brasil et al., 2016; Costa et al., 2016).

Taking the important role of freshwater ecosystems for the global carbon budget into consideration, the investigation of man-made lakes is poorly understood especially in tropical semi-arid reservoirs with high levels of eutrophication allied to prolonged drought as previously studied (Braga et al., 2015). The aim of this study was to evaluate the partial pressure of carbon dioxide $\left(p \mathrm{CO}_{2}\right)$ over time in tropical semi-arid eutrophic 
reservoirs. Additionally, it aims to evaluate how water quality (trophic state) and water level fluctuations affect the $\mathrm{CO}_{2}$ metabolism. The authors believe that water fluctuations allied to eutrophication are regionally key factors in carbon dioxide metabolism during a prolonged drought as part of climate change scenarios. Due to the fact that climate change is reducing the rainfall in the tropical semi-arid as well as enhancing the frequency of extreme droughts, and probably increases eutrophication (Roland et al., 2012; Sarmento et al., 2013), it is extremely important to figure out the role of the eutrophic semi-arid reservoirs on the carbon balance and how they behave facing these changes in climate.

\section{Methods}

\subsection{Water supply reservoirs}

This study was performed in four reservoirs in the tropical semi-arid region in the northeast of Brazil located in Seridó River basin, Piranhas Açu River sub-basin in the state of Rio Grande do Norte: Dourado (06 $14^{\circ} 48^{\prime \prime} S$; 3630'30"W), Gargalheiras

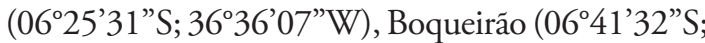
$\left.36^{\circ} 37^{\prime} 21^{\prime \prime} \mathrm{W}\right)$ and Passagem das Traíras (6 $30^{\circ} 46^{\prime \prime} \mathrm{S}$; $36^{\circ} 56^{\prime \prime} 14^{\prime \prime W}$ ) (Figure 1; morphometric and hydrological information detailed in (Mendonça Junior et al., 2014). This region is dominated by the Caatinga biome (white vegetation), where the soils are predominantly Litolic Neosols (IDEMA, 2012). The regional climate is tropical semi-arid, type BSw'h' by Köppen (Kottek et al., 2006). Average temperatures exceed $25^{\circ} \mathrm{C}$ and there is a pronounced temporal and spatial variation of annual rainfall (300-1000 mm.year ${ }^{-1}$. The rainy season is usually concentrated in a short period (3-5 months) and the region is characterized by a negative water balance (Sampaio, 1995). During this study, the rain was concentrated in the beginning of 2011 and in the following months there was hardly any rain (for details see Mendonça Junior et al., 2014).

\subsection{Sampling and data collection}

The reservoirs were sampled monthly: Boqueirão reservoir from September 2011 to December 2014; Passagem das Traíras reservoir from September 2011 to November 2013; Dourado reservoir from May 2011 to November 2013 and Gargalheiras reservoir from December 2010 to July 2014. Every reservoir was sampled at 3 stations: close to the dam; in the middle, and close to the main inflow river in order

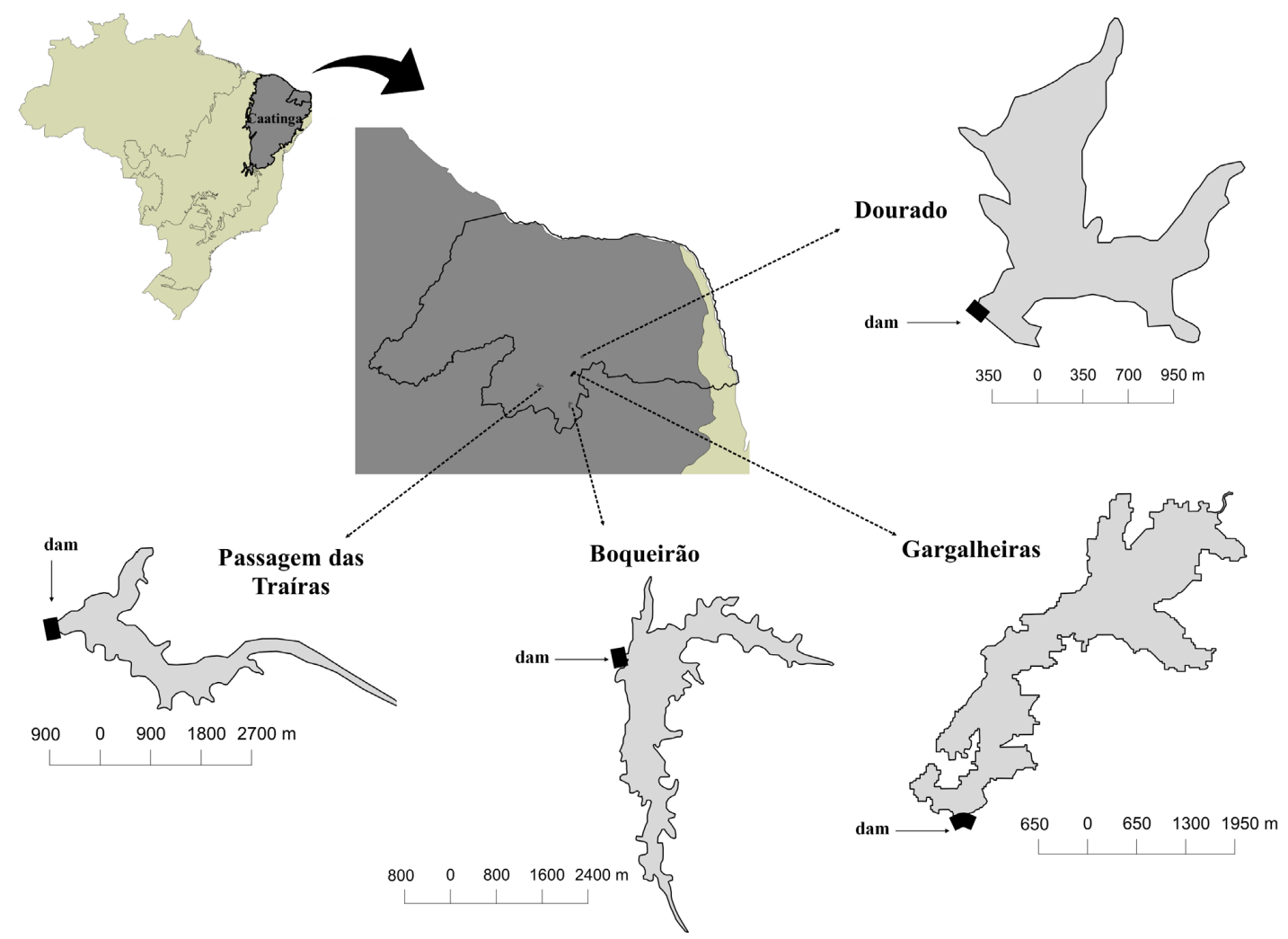

Figure 1. Location of the studied water supply reservoirs in the semi-arid region, Brazil. The sampling stations are indicated in the maps. 
to represent their spatial variability. All samplings were performed between 9 and $12 \mathrm{am}$.

Samples for $\mathrm{pH}$ and alkalinity measurements and further partial pressure of carbon dioxide $\left(p \mathrm{CO}_{2}\right)$ estimations were taken from the sub-surface into a polyethylene flask using a proper device that allowed a three times overflow leaving no headspace. These samples were kept refrigerated in the dark to reduce metabolic activity until they arrived at the laboratory for analysis (c.a. 4 hours). This procedure was previously evaluated and did not affect $\mathrm{CO}_{2}$ concentrations in the water.

Additionally, water samples were taken with a Van Dorn bottle for total phosphorous (TP) and chlorophyll- $a$ (Chl- $a$ ) determinations. Water transparency was measured through a Secchi disk. Chemical measurements $(\mathrm{pH}$, dissolved oxygen, temperature) were conducted with a sonde (Hydrolab DS5). In the laboratory, the alkalinity was determined (Golterman et al., 1978) and subsequently calculated through the Alcagram program (Carmouze, 1994). TP and Chl-a were determined by colorimetric methods for spectrophotometer, according to Valderrama (1981) and Jespersen \& Christoffersen (1988) methods, respectively. $p \mathrm{CO}_{2}$ concentrations were calculated from $\mathrm{pH}$ and alkalinity measurements (according to Stumm \& Morgan 1996) with corrections for temperature, altitude and ionic strength following Cole et al. (1994) and Weiss (1974). pH was measured with a precision of $0.01 \mathrm{pH}$ units with a calibrated $\mathrm{pH}$ meter (Tecnal Tec-3MP) and alkalinity was measured by Gran's titration (APHA 1998). In this study, we considered the atmospheric $\mathrm{CO}_{2}$ concentration at $390 \mu \mathrm{atm}$. It was recently shown that there is an over-estimation of $p \mathrm{CO}_{2}$ from the alkalinity method (the method used here) when water $\mathrm{pH}$ is below 6.5-7.0, when compared to direct measurements with "in situ" infrared gas analyzers [IRGA] (Abril et al., 2015). However, the $p \mathrm{CO}_{2}$ estimation from alkalinity presents no deviation from $p \mathrm{CO}_{2}$ estimated by direct measurements in waters with pH above 7.0 (Abril et al., 2015). As the great majority of the $\mathrm{pH}$ measured in our samples were above 8.0 (see Table 1) and just very few $\mathrm{pH}$ measurements were between 6.0 and 7.0, we are confident that our $\mathrm{CO}_{2}$ data is very precise and robust.

\subsection{Statistics}

Correlation analysis was used to detect relations among the calculated $p \mathrm{CO}_{2}$, water volume and Chl-a. Only the most influential variables were showed with a variable retention criterion of $p=0.05$. Data of Chl- $a$, volume and $p \mathrm{CO}_{2}$ were log transformed to fulfill the normality requirements. All statistical tests were performed using Sigmaplot software (Systat software Inc., California, U.S.A.).

\section{Results}

During the period of study all reservoirs drastically diminished their volumes and Dourado, Boqueirão and Passagem das Traíras reservoirs were close to $0 \%$ of the total volume at the end of the sampling periods (Figure 2). It was not possible to observe any annual pattern for any of the measured limnological parameters (data not shown). Temperature was on average above $26^{\circ} \mathrm{C}$ in all four aquatic ecosystems, reaching up to $34^{\circ} \mathrm{C}$ in Passagem das Trairas. All the other physical, chemical and biological measured limnological parameters presented high variability during the study and are summarized in Table 1. We highlight the average TP concentrations above $100 \mu \mathrm{g} . \mathrm{L}^{-1}$, except for Boqueirão and all maximum TP concentrations above $300 \mu \mathrm{g} \cdot \mathrm{L}^{-1}$. Moreover,

Table 1. Median values, maximum and minimum (between parentheses) of limnological variables of each semi-arid reservoir studied during the period 2010-2013.

\begin{tabular}{|c|c|c|c|c|}
\hline Variables & $\begin{array}{c}\text { Boqueirão } \\
(n=87)\end{array}$ & $\begin{array}{l}\text { Passagem das Traíras } \\
\qquad(\mathrm{n}=76)\end{array}$ & $\begin{array}{l}\text { Gargalheiras } \\
(n=130)\end{array}$ & $\begin{array}{l}\text { Dourado } \\
(n=122)\end{array}$ \\
\hline $\mathrm{T}\left({ }^{\circ} \mathrm{C}\right)$ & $26.7(23.90-28.83)$ & $28.75(24.47-34.05)$ & $26.9(24.10-33.69)$ & $26.4(23.56-30.21)$ \\
\hline OD $\left(\mathrm{mg} \cdot \mathrm{L}^{-1}\right)$ & $8.01(3.7-11.0)$ & $10.40(0.0-19.8)$ & $8.7(2.6-29.1)$ & $7.5(2.4-15.0)$ \\
\hline Zmax (m) & $8.15(1.4-15.0)$ & $6.05(0.6-12.8)$ & $7.3(0.5-20.2)$ & $2.95(0.3-9.7)$ \\
\hline Secchi (m) & $1.50(0.3-4.3)$ & $0.30(0.2-5.6)$ & $0.35(0.1-2.5)$ & $0.30(0.1-1.71)$ \\
\hline Turbidez (NTU) & $4.61(1.3-37.0)$ & $29.5(6.8-118.0)$ & $27.0(5.4-119.0)$ & 23 (5.3-293.0) \\
\hline $\mathrm{pH}$ & $8.76(7.0-10.3)$ & $8.80(6.0-10.5)$ & $8.78(6.7-10.5)$ & $8.27(6.3-9.4)$ \\
\hline TP $\left(\mu g . L^{-1}\right)$ & $37.4(3.5-272.0)$ & $121.4(33.5-567.0)$ & 156.5 (39.5-769.5) & $109.6(20.4-834.2)$ \\
\hline Chl-a $\left(\mu \mathrm{g} . \mathrm{L}^{-1}\right)$ & $13.7(0.2-330.9)$ & $156.1(37.4-460.4)$ & $154.4(3.4-362.1)$ & 78.8 (5.7-777.2) \\
\hline$p \mathrm{CO}_{2}$ ( $\mu$ atm) & $359(5.26-11,473)$ & $275(3-76,032.63)$ & $354(3-36,428)$ & $884(64-52,228)$ \\
\hline
\end{tabular}

$\mathrm{T}=$ temperature, $\mathrm{OD}=$ dissolved oxygen, $\mathrm{Zmax}=$ maximum depth, $\mathrm{TP}=$ total phosphorus, $\mathrm{Chl}-\mathrm{a}=$ chlorophyll-a, $p \mathrm{CO}_{2}=$ partial pressure of carbon dioxide. 


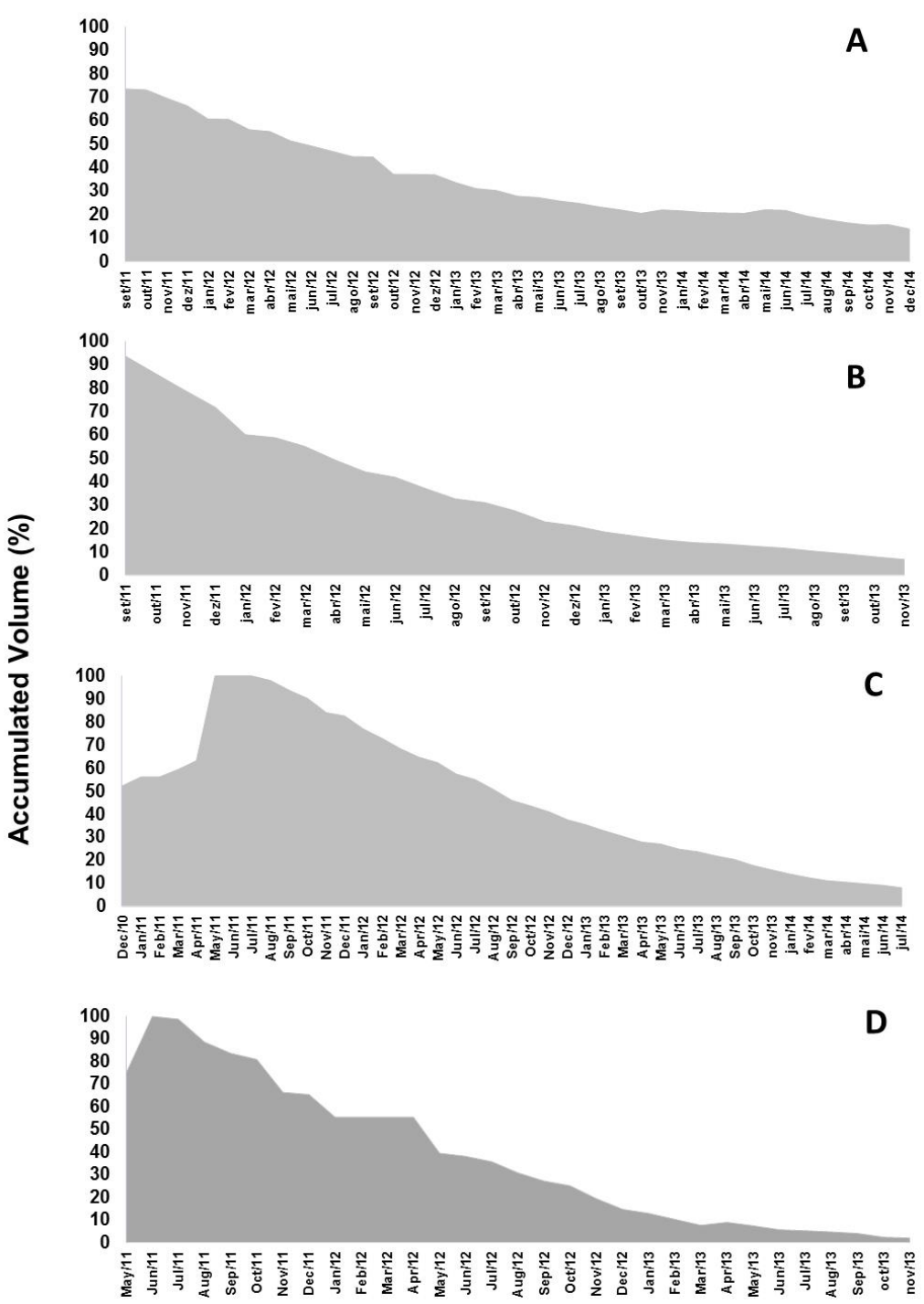

Figure 2. Monthly percentage of water volume (\%) of each reservoir during the study: (A) Boqueirão Reservoir; (B) Passagem das Traíras Reservoir; (C) Gargalheiras Reservoir; (D) Dourado Reservoir.

the average Chl- $a$ concentrations varied from 13 to higher than $150 \mu \mathrm{g} \cdot \mathrm{L}^{-1}$.

Boqueirão, Passagem das Traíras and Gargalheiras presented average $p \mathrm{CO}_{2}$ below saturation (atmospheric concentration at $390 \mu \mathrm{atm})$ while Dourado was on average above saturation (Table 1). However, the $p \mathrm{CO}_{2}$ varied by three orders of magnitude in all four studied ecosystems (Table 1) and $51 \%$ of the measurements in all reservoirs $(\mathrm{n}=415)$ recorded $\mathrm{CO}_{2}$ super-saturation (above $390 \mu \mathrm{atm}$ ). In Boqueirão, Passagem das Traíras and Gargalheiras reservoirs, respectively, $53 \%, 60 \%$ and $56 \%$ of the samples $(\mathrm{n}=87$; $\mathrm{n}=76 ; \mathrm{n}=130$ ) were below $\mathrm{CO}_{2}$ saturation in the water, while in Dourado only $33 \%$ of the samples $(\mathrm{n}=122)$ were below saturation.
The authors recorded positive correlations between Chl- $a$ and accumulated volume (\%) for Dourado $\left(\mathrm{R}^{2}=0.67 ; p<0.001 ; \mathrm{n}=42\right)$, Boqueirão $\left(\mathrm{R}^{2}=0.62 ; p<0.001 ; \mathrm{n}=39\right)$ and Passagem das Traíras $\left(\mathrm{R}^{2}=0.56 ; p<0.001 ; \mathrm{n}=38\right)$ reservoirs, but not for Gargalheiras reservoir (Figure 3). We also recorded positive correlations between $p \mathrm{CO}_{2}$ and accumulated volume (\%) for Dourado $\left(\mathrm{R}^{2}=0.42\right.$; $p<0.001 ; \mathrm{n}=42)$, Passagem das Traíras $\left(\mathrm{R}^{2}=0.20\right.$; $p=0.021 ; \mathrm{n}=38)$ and Gargalheiras $\left(\mathrm{R}^{2}=0.42\right.$; $p<0.001 ; \mathrm{n}=46$ ) reservoirs, but not for Boqueirão reservoir (Figure 4). Additionally, we recorded negative correlations between $p \mathrm{CO}_{2}$ and Chl- $a$ for all four reservoirs: Dourado $\left(\mathrm{R}^{2}=0.37 ; p<0.001\right.$; $\mathrm{n}=122)$, Passagem das Traíras $\left(\mathrm{R}^{2}=0.042 ; p<0.01\right.$; $\mathrm{n}=76)$, Boqueirão $\left(\mathrm{R}^{2}=0.17 ; p<0.001 ; \mathrm{n}=87\right)$ 

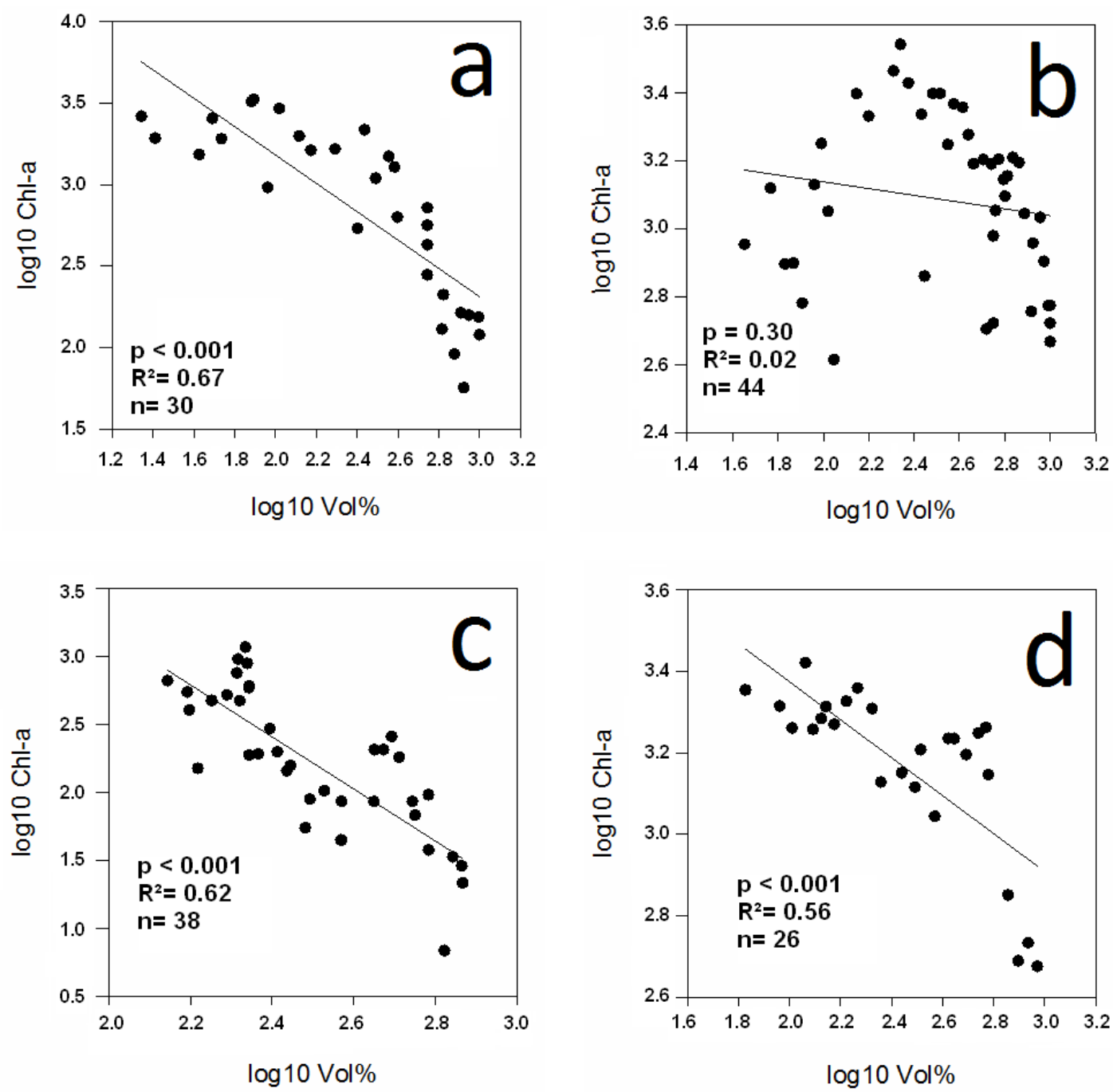

Figure 3. Linear regression between chlorophyll- $a$ and volume of all reservoirs over the period of study. (a) Boqueirão Reservoir; (b) Passagem das Traíras Reservoir; (c) Gargalheiras Reservoir; (d) Dourado Reservoir. All data were log transformed.

and Gargalheiras $\left(\mathrm{R}^{2}=0.09 ; p<0.001 ; \mathrm{n}=130\right)$ (Figure 4).

\section{Discussion}

The current study was performed in four man-made reservoirs located in a tropical semi-arid region during a prolonged drought period from 2012 to 2014 (Mendonça Júnior et al., 2014; Costa et al., 2016). It is already documented that the regular annual dry periods in this area increase the trophic state of the reservoirs and they are usually mostly in eutrophic conditions (Brasil et al., 2016). In fact, our data corroborate that the studied reservoirs were under eutrophic conditions during the current study, according to the classification proposed for arid and semi-arid aquatic ecosystems by Thornton \& Rast (1993). Besides, this study also corroborated the reduction of the water volume of the lakes intensified eutrophication, by concentrating nutrients, as revealed by the negative correlations between \% of volume and Chl- $a$ concentration.

The global ecosystem metabolism is based on a balance between the gross primary production (GPP) and the organic matter consumption (e.g. net ecosystem respiration [R]), which is known as net ecosystem production (NEP). Both production and consumption are positively affected by temperature, but GPP is also influenced by nutrient availability (e.g. phosphorus), while $\mathrm{R}$ is affected by the organic matter concentration and availability (Dodds \& Cole, 2007). Therefore, the interaction between these components directly affects the carbon balance 
a

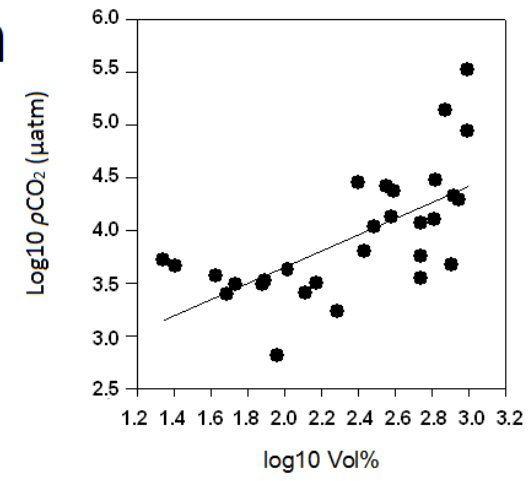

b

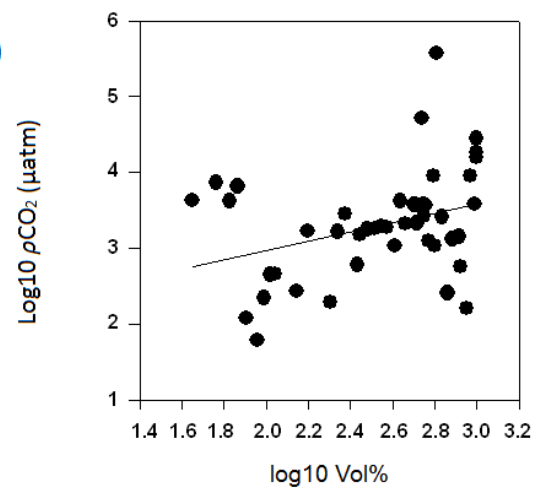

C

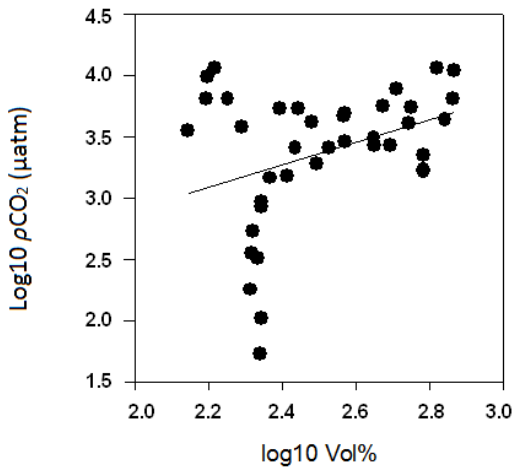

d

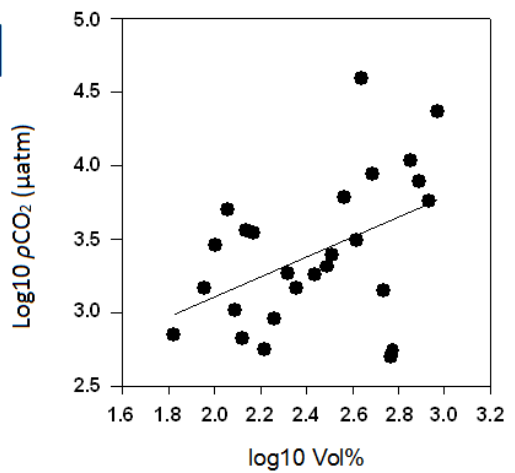

e

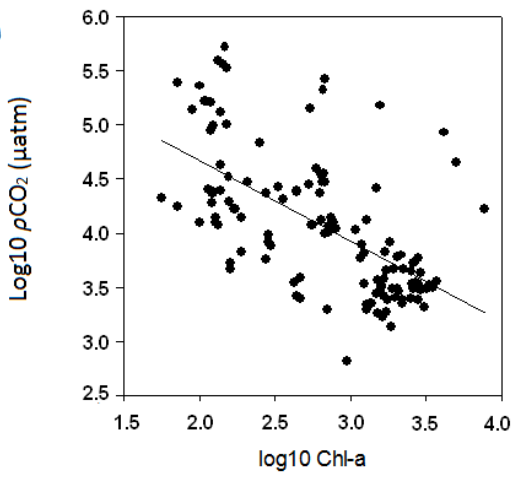

$f$

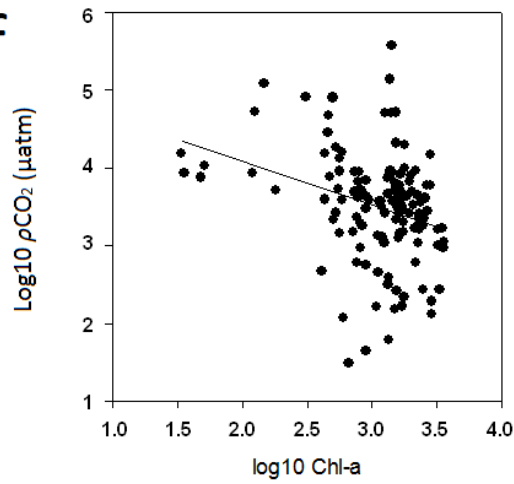

g

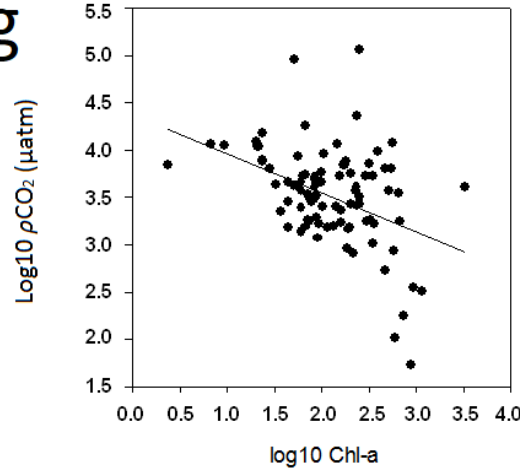

h

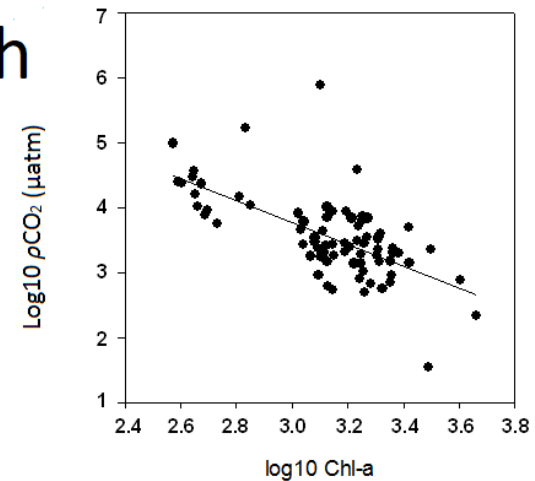

Figure 4. Linear regression analysis of variation in $p \mathrm{CO}_{2}$ vs. \% of accumulated volume (a-d) and $p \mathrm{CO}_{2} v$ s. chlorophyll- $a$ (e-h). Boqueirão Reservoir (a and e), Passagem das Traíras Reservoir (b and f), Gargalheiras Reservoir (c and g) and Dourado Reservoir (d and h). All data were log transformed. 
in ecosystems and, consequently, the concentrations of $\mathrm{CO}_{2}$ in the water.

As primary production increases with eutrophication state, one could expect that these eutrophic ecosystems should present predominantly autotrophic conditions (i.e. prevalence of sub-saturation of $\mathrm{CO}_{2}$ in the water) and function as carbon sinks from the atmosphere (Cole et al., 2001) as in other eutrophic aquatic ecosystems in higher latitudes (Balmer \& Downing, 2011; Pacheco et al., 2013). In fact, in this paper, extremely high Chl-a concentrations were observed (a proxy for primary production) and consistent negative relations between $p \mathrm{CO}_{2}$ and $\mathrm{Chl}-a$, which suggestedphytoplankton $\mathrm{CO}_{2}$ uptake (via photosynthesis) from the water. Furthermore, the prolonged drought during this study, besides favoring the $\mathrm{CO}_{2}$ uptake by phytoplankton due to eutrophication and high primary production, resulted in negligible input of allochthonous organic matter into the reservoirs (Mendonça Junior et al., 2014; Costa et al., 2016), which probably did not stimulate ecosystem respiration favoring autotrophy (Dodds \& Cole, 2007). However, we did not record the prevalence of $\mathrm{CO}_{2}$ sub-saturation, but similar overall frequencies of super and sub-saturation. Thus, we did not register consistent autotrophic conditions in the studied reservoirs.

A recent study performed in a tropical eutrophic reservoir in the semi-arid demonstrated net heterotrophy due to high temperatures (Almeida et al., 2016). In fact, the $p \mathrm{CO}_{2}$ was previously positively correlated to temperature in tropical ecosystems (Marotta et al., 2009) once higher temperatures increases respiration rates (Amado et al., 2013). In agreement, other tropical eutrophic reservoirs located in wetter areas (such as Cerrado and Atlantic Forest biomes) were also classified as predominantly super-saturated in $\mathrm{CO}_{2}$ (Roland et al., 2010). Thus, it is not yet clear what drives heterotrophic and autotrophic conditions in the semi-arid eutrophic reservoirs, but prolonged droughts seem to stimulate primary production driving the metabolism towards the autotrophic state.

It was recently demonstrated that $p \mathrm{CO}_{2}$ can be overestimated when it is estimated using the alkalinity method in organic-rich and acidic waters (Abril et al., 2015). The reservoirs studied here presented predominantly basic $\mathrm{pH}$ and almost no input of organic matter from the watershed
(Table 1, Mendonça Junior et al., 2014). Thus, it is reasonable to believe that this methodological bias did not affect the $\mathrm{CO}_{2}$ pattern discussed here.

The Earth is currently facing changes in the global climate. Current predictions suggest temperature increase and rainfall reduction (until the end of this century) in the tropical semi-arid region is negatively affecting the water supply to the reservoirs (Marengo et al., 2009). Consequently, these ecosystems would turn into a more eutrophic state or dry out (Roland et al., 2012). On one hand, the temperature increase could lead to increasing heterotrophic conditions by stimulating respiration. On the other hand, it could lead to increasing autotrophic conditions due to eutrophication (Moss et al., 2011). Taking into account that the low volume could result in inorganic turbidity from the sediment resuspension (Costa et al., 2016) and sediment respiration relevance to the net metabolism in reservoirs (Cardoso et al., 2013), predicting the effect of climate changes to carbon balance in the tropical semi-arid reservoirs is not straightforward and should be done with caution. Nonetheless, the current study suggests that the eutrophic reservoirs have a fundamental role in the regional carbon cycle and can potentially increase the absorption of atmospheric $\mathrm{CO}_{2}$ in the current century. It is important to point out that further research is required for better understanding the regulation of $\mathrm{CO}_{2}$ balance, regarding the physical and chemical characteristics of the man-made systems, to quantify the contribution of these systems to the global carbon cycle.

\section{Conclusions}

- Semi-arid eutrophic reservoirs are not consistently autotrophic because of high temperatures and intense heterotrophic processes;

- The prolonged droughts favor autotrophic process and consequent $\mathrm{CO}_{2}$ sub-saturation in the water of the semi-arid tropical eutrophic reservoirs;

- The tropical semi-arid eutrophic reservoirs present great regional relevance to the carbon dioxide balance;

- Changes in the climate will directly affect how the tropical semi-arid reservoirs function in the carbon cycling. 


\section{Acknowledgements}

We are thankful to FINEP (Financier of Studies and Projects) process $n^{\circ} 52009$ and CNPq (Brazilian National Research Council) for financial support (A. A. Grant \# 475537/2012-2); and CAPES (Coordination of Improvement of Higher Education Personnel) for granting master's scholarship and for financial support (A. A.Grant \# 0756/2014 - PVE). We are also grateful to Anderson Felipe de Medeiros Bezerra, Ângela Marília Freitas Galvão, Gustavo Girão Braga, José Neuciano Pinheiro de Oliveira, Laíssa de Macêdo Torres, Larissa Mirelly Carlota Cavalcanti, Mariana R. A. da Costa e Maria da Conceiçấo de Souza for technical support (at field and laboratory analyses). We thank Dr. Odete Rocha for valuable discussions and comments on the manuscript. We also thank Nicola Wood, Valéria Amado and Bruna Vargas for the English review.

\section{References}

ABRIL, G., BOUILLON, S., DARCHAMBEAU, F., TEODORU, C.R., MARWICK, T.R., TAMOOH, F., OCHIENG OMENGO, F., GEERAERT, N., DEIRMENDJIAN, L., POLSENAERE, P. and BORGES, A.V. Technical note: Large overestimation of $p \mathrm{CO} 2$ calculated from $\mathrm{pH}$ and alkalinity in acidic, organic-rich freshwaters. Biogeosciences, 2015, 12(1), 67-78. http://dx.doi.org/10.5194/bg-12-67-2015.

ALMEIDA, R.M., NÓBREGA, G.N., JUNGER, P.C., FIGUEIREDO, A.V., ANDRADE, A.S., MOURA, C.G.B., TONETTA, D., OLIVEIRA JUNIOR, E., ARAÚJO, F., RUST, F., PIÑEIRO-GUERRA, J.M., MENDONÇA JUNIOR, J., MEDEIROS, L.R., PINHEIRO, L., MIRANDA, M., COSTA, M.R.A., MELO, M.L., NOBRE, R.L.G., BENEVIDES, T., ROLAND, F., DE KLEIN, J., BARROS, N., MENDONÇA, R., BECKER, V., HUSZAR, V.L.M. and KOSTEN, S. High primary production contrasts with intense carbon emission in a eutrophic tropical reservoir. Frontiers in Microbiology, 2016, 7, 1-13. http://dx.doi.org/10.3389/fmicb.2016.00717.

AMADO, A.M., MEIRELLES-PEREIRA, F., VIDAL, L.O., SARMENTO, H., SUHETT, A.L., FARJALLA, V.F., COTNER, J.B. and ROLAND, F. Tropical freshwater ecosystems have lower bacterial growth efficiency than temperate ones. Frontiers in Microbiology, 2013, 4, 167. PMID: 23801986. http://http://dx.doi.org/10.3389/fmicb.2013.00167.

AMERICAN PUBLIC HEALTH ASSOCIATION APHA. Standard Methods for the Examination of Water and Wastewater. 20th ed. Washington DC: American Public Health Association, 1998.

BALMER, M.B. and DOWNING, J.A. Carbon dioxide concentrations in eutrophic lakes: undersaturation implies atmospheric uptake. Inland Waters, 2011, 1(2), 125-132. http://dx.doi.org/10.5268/IW1.2.366.

BARBOSA, J.E.D.L., MEDEIROS, E.S.F., BRASIL, J., CORDEIRO, R.D.S., CRISPIM, M.C.B. and SILVA, G.H.G.D. Aquatic systems in semi-arid Brazil: limnology and management. Acta Limnologica Brasiliensia, 2012, 24(1), 103-118. http://dx.doi. org/10.1590/S2179-975X2012005000030.

BARROS, N., COLE, J.J., TRANVIK, L.J., PRAIRIE, Y.T., BASTVIKEN, D., HUSZAR, V.L.M., DEL GIORGIO, P. and ROLAND, F. Carbon emission from hydroelectric reservoirs linked to reservoir age and latitude. Nature Geoscience, 2011, 4(9), 593-596. http://dx.doi.org/10.1038/ngeo1211.

BRAGA, G.G., BECKER, V., OLIVEIRA, J.N.P., MENDONÇA JUNIOR, J.R., BEZERRA, A.F.M., TORRES, L.M., GALVÃO, Â.M.F. and MATTOS, A. Influence of extended drought on water quality in tropical reservoirs in a semi-arid region. Acta Limnologica Brasiliensia, 2015, 27(1), 15-23. http:// dx.doi.org/10.1590/S2179-975X2214.

BRASIL, J., ATTAYDE, J.L., VASCONCELOS, F.R., DANTAS, D.D.F. and HUSZAR, V. Droughtinduced water-level reduction favors cyanobacteria blooms in tropical shallow lakes. Hydrobiologia, 2016, 770(1), 145-164. http://dx.doi.org/10.1007/ s10750-015-2578-5.

CARDOSO, S.J., VIDAL, L.O., MENDONCA, R.F., TRANVIK, L.J., SOBEK, S. and ROLAND, F. Spatial variation of sediment mineralization supports differential $\mathrm{CO} 2$ emissions from a tropical hydroelectric reservoir. Frontiers in Microbiology, 2013, 4, 101. http://dx.doi.org/10.3389/ fmicb.2013.00101.

CARMOUZE, J.P.O. Metabolismo dos ecossistemas aquáticos - Fundamentos teóricos, métodos de estudo e análises quimicas. São Paulo: Editora FAPESP, 1994.

CHELLAPPA, N.T., CHELLAPPA, T., CÂMARA, F.R.A., ROCHA, O. and CHELLAPPA, S. Impact of stress and disturbance factors on the phytoplankton communities in Northeastern Brazil reservoir. Limnologica, 2009, 39(4), 273-282. http://dx.doi. org/10.1016/j.limno.2009.06.006.

COLE, J.J., CARACO, N.F., COLE, J.J. and CARACO, N.F. Carbon in catchments: connecting terrestrial carbon losses with aquatic metabolism. Marine \& Freshwater Research, 2001, 52(1), 101-110. http:// dx.doi.org/10.1071/MF00084.

COLE, J.J., CARACO, N.F., KLING, G.W. and KRATZ, T.K. Carbon-Dioxide Supersaturation in the Surface Waters of Lakes. Science, 1994, 265(5178), 1568-1570. http://dx.doi.org/10.1126/ science.265.5178.1568. PMid:17801536.

COLE, J.J., PRAIRIE, Y.T., CARACO, N.F., MCDOWELL, W.H., TRANVIK, L.J., STRIEGL, 
R.G., DUARTE, C.M., KORTELAINEN, P., DOWNING, J.A., MIDDELBURG, J.J. and MELACK, J. Plumbing the global carbon cycle: Integrating inland waters into the terrestrial carbon budget. Ecosystems, 2007, 10(1), 171-184. http:// dx.doi.org/10.1007/s10021-006-9013-8.

COSTA, M.R.A., ATTAYDE, J.L. and BECKER, V. Effects of water level reduction on the dynamics of phytoplankton functional groups in tropical semiarid shallow lakes. Hydrobiologia, 2016, 778(1), 75 89. http://dx.doi.org/10.1007/s10750-015-2593-6.

DODDS, W. and COLE, J.J. Expanding the concept of trophic state in aquatic ecosystems: it's not just the autotrophs. Aquatic Sciences, 2007, 69(4), 427-439. http://dx.doi.org/10.1007/s00027-007-0922-1.

FINLAY, K., LEAVITT, P.R., WISSEL, B. and PRAIRIE, Y.T. Regulation of spatial and temporal variability of carbon flux in six hard-water lakes of the northern great plains. Limnology and Oceanography, 2009, 53(6), 2553-2564. http://dx.doi.org/10.4319/ lo.2009.54.6_part_2.2553.

FORBES, M.G., DOYLE, R.D., SCOTT, J.T., STANLEY, J.K., HUANG, H., FULTON, B.A. and BROOKS, B.W. Carbon sink to source: longitudinal gradients of planktonic P:R ratios in subtropical reservoirs. Biogeochemistry, 2012, 107(1-3), 81-93. http://dx.doi.org/10.1007/s10533-010-9533-3.

FRIEDL, G. and WÜEST, A. Disrupting biogeochemical cycles consequences of damming. Aquatic Sciences, 2002, 64(1), 55-65. http://dx.doi.org/10.1007/ s00027-002-8054-0.

GOLTERMAN, H.L., CLIMO, R.S. and OHNSTAD, M.A.M. Methods for physical and chemical analysis of freshwaters. Oxford: Blackwell Scientific Publications, 1978. Handbooks, no. 8.

HUMBORG, C., BlOMQVIST, S., AVSAN, E., BERGENSUND, Y., SMEDBERG, E., BRINK, J. and MÖRTH, C.M. Hydrological alterations with river damming in northern Sweden: Implications for weathering and river biogeochemistry. Global Biogeochemical Cycles, 2002, 16(3), 12-1. http:// dx.doi.org/10.1029/2000GB001369.

INSTITUTO DE DESENVOLVIMENTO SUSTENTÁVEL E MEIO AMBIENTE DO RIO GRANDE DO NORTE - IDEMA. Perfil do seu município. Rio Grande do Norte: IDEMA, 2012 [viewed 7 Feb 2017]. Available from: http://idema. rn.gov.br/

JESPERSEN, A.M. and CHRISTOFFERSEN, K. Measurements of chlorophyll-a from phytoplankton using ethanol as extraction solvent. Archiv für Hydrobiologie, 1988, 109, 445-454.

KOTTEK, M., GRIESER, J., BECK, C., RUDOLF, B. and RUBEL, F. World Map of the KöppenGeiger climate classification updated. Meteorologische
Zeitschrift, 2006, 15(3), 259-263. http://dx.doi. org/10.1127/0941-2948/2006/0130.

LAZZARINO, J.K., BACHMANN, R.W., HOYER, M.V. and CANFIELD, D.E. Carbon dioxide supersaturation in Florida lakes. Hydrobiologia, 2009, 627(1), 169-180. http://dx.doi.org/10.1007/ s10750-009-9723-y.

MARENGO, J.A., JONES, R., ALVES, L.M. and VALVERDE, M.C. Future change of temperature and precipitation extremes in South America as derived from the PRECIS regional climate modeling system. International Journal of Climatology, 2009, 29(15), 2241-2255. http://dx.doi.org/10.1002/ joc. 1863.

MAROTTA, H., DUARTE, C.M., SOBEK, S. and ENRICH-PRAST, A. Large CO2 disequilibria in tropical lakes. Global Biogeochemical Cycles, 2009, 23, 1-4. http://dx.doi.org/10.1029/2008GB003434.

MEDEIROS, L.C., MATTOS, A., LÜRLING, M. and BECKER, V. Is the future blue-green or brown? The effects of extreme events on phytoplankton dynamics in a semi-arid man-made lake. Aquatic Ecology, 2015, 49(3), 293-307. http://dx.doi.org/10.1007/s10452015-9524-5.

MENDONÇA JUNIOR, J.R., BECKER, V. and AMADO, A.M. Variação Temporal do Dióxido de Carbono em Reservatórios Eutrofizados da Região Semiárida Tropical. In: A. Mattos and K.M.C. Mattos, eds. Projeto MEVEMUC: Monitoramento da Evaporação e as Mudanças Climáticas. João Pessoa: Moura Ramos Gráfica e Editora Ltda, 2014, pp. 361-380.

MENDONÇA, R., KOSTEN, S., SOBEK, S., BARROS, N., COLE, J.J., TRANVIK, L. and ROLAND, F. Hydroeletric carbon sequestration. Nature Geoscience, 2012, 5(12), 838-840. http:// dx.doi.org/10.1038/ngeo1653.

MOSS, B., KOSTEN, S., MEERHOFF, M.R.W., JEPPESEN, E., MAZZEO, N., HAVENS, K., LACEROT, G., LIU, Z., DE MEESTER, L., PAERL, H. and SCHEFFER, M. Allied attack: climate change and eutrophication. Inland Waters, 2011, 1, 101-105. http://doi: 10.5268/IW-1.2.359.

OKI, T. and KANAE, S. Global hydrological cycles and world water resources. Science, 2006, 313(5790), 1068-1072. http://dx.doi.org/10.1126/ science. 1128845 .

PACHECO, F.S., ROLAND, F. and DOWNING, J.A. Eutrophication reverses whole-lake carbon budgets. Inland Waters, 2013, 4(1), 41-48. http://dx.doi. org/10.5268/iw-4.1.614.

RAYMOND, P.A., HARTMANN, J., LAUERWALD, R., SOBEK, S., MCDONALD, C., HOOVER, M., BUTMAN, D., STRIEGL, R., MAYORGA, E., HUMBORG, C., KORTELAINEN, P., DÜRR, H., MEYBECK, M., CIAIS, P. and GUTH, P. 
Global carbon dioxide emissions from inland waters. Nature, 2013, 503(7476), 355-359. http://dx.doi. org/10.1038/nature12760. PMid:24256802.

ROLAND, F., HUSZAR, V.L.M., FARJALLA, V.F., ENRICH-PRAST, A., AMADO, A. and OMETTO, J.P.H.B. Climate change in Brazil: perspective on the biogeochemistry of inland waters. Brazilian Journal of Biology $=$ Revista Brasileira de Biologia, 2012, 72(3), 709-722. Supplement. http:// dx.doi.org/10.1590/S1519-69842012000400009. PMid:23011300.

ROLAND, F., VIDAL, L.O., PACHECO, F.S., BARROS, N.O., ASSIREU, A., OMETTO, J., CIMBLERIS, A.C.P. and COLE, J.J. Variability of carbon dioxide flux from tropical (Cerrado) hydroelectric reservoirs. Aquatic Sciences, 2010, 72(3), 283-293. http://dx.doi.org/10.1007/s00027010-0140-0.

ROSENBERG, D.M., MCCULLY, P. and PRINGLE, C.M. Global-scale environmental effects of hydrological alterations: introduction. Bioscience, 2000, 50(9), 746-751. http://dx.doi. org/10.1641/0006-3568(2000)050[0746:GSEEO $\mathrm{H}] 2.0 . \mathrm{CO} ; 2$.

SAMPAIO, E.V.S.B. Overview of the Brazilian Caatinga. In: H.A. MOONEY, S.H. BULLOCK and E. MEDINA, eds. Dry tropical forest. Cambridge: Cambridge University Press, 1995, pp. 35-63.

SARMENTO, H., AMADO, A.M. and DESCY, J.P. Climate change in tropical fresh waters (comment on the paper 'Plankton dynamics under different climatic conditions in space and time' by de Senerpont Domis et al., 2013). Freshwater Biology, 2013, 58(10), 2208-2210. http://dx.doi.org/10.1111/fwb.12203.

SMITH, V.H. and SCHINDLER, D.W. Eutrophication science: where do we go from here? Trends in Ecology \& Evolution, 2009, 24(4), 201-207. http://dx.doi. org/10.1016/j.tree.2008.11.009. PMid:19246117.

SMITH, V.H., JOYE, S.B. and HOWARTH, R.W. Eutrophication of freshwater and marine ecosystems. Limnology and Oceanography, 2006, 51(1/2), 351355. http://dx.doi.org/10.4319/lo.2006.51.1_ part_2.0351.

SOARES, M.C., MARINHO, M.M., AZEVEDO, S.M.O.F., BRANCO, C.W.C. and HUSZAR, V.L.M. Eutrophication and retention time affecting spatial heterogeneity in a tropical reservoir. Limnologica, 2012, 42(3), 197-203. http://dx.doi. org/10.1016/j.limno.2011.11.002.

ST. LOUIS, V.L., KELLY, C.A., DUCHEMIN, É., RUDD, J.W.M. and ROSENBERG, D.M. Reservoir surfaces as sources of greenhouse gases to the atmosphere: a global estimate. Bioscience, 2000, 50(9), 766-775. http://dx.doi.org/10.1641/00063568(2000)050[0766:RSASOG]2.0.CO;2.

STUMM, W. and MORGAN, J.J. Aquatic chemistry: chemical equilibria and rates in natural waters. Hoboken: Wiley-Interscience, 1996.

THORNTON, J.A. and RAST, W. Test of hypotheses relating to the comparative limnology and assessment of eutrophication in semi-arid manmade lakes. In: $M$ STRASKRABA, J.G. TUNDISI and A. DUNCAN, eds. Comparative reservoir limnology and water quality management. London: Kluwer Academic Publishers, 1993, pp. 1-24.

TRANVIK, L.J., DOWNING, J.A., COTNER, J.B., LOISELLE, S.A., STRIEGL, R.G., BALLATORE, T.J., DILLON, P., FINLAY, K., FORTINO, K., KNOLL, L.B., KORTELAINEN, P.L., KUTSER, T., LARSEN, S., LAURION, I., LEECH, D.M., MCCALLISTER, S.L., MCKNIGHT, D.M. MELACK, J.M., OVERHOLT, E., PORTER, J.A., PRAIRIE, Y., RENWICK, W.H., ROLAND, F., SHERMAN, B.S., SCHINDLER, D.W., SOBEK, S., TREMBLAY, A., VANNI, M.J., VERSCHOOR, A.M., VON WACHENFELDT, E. and WEYHENMEYER, G.A. Lakes and reservoirs as regulators of carbon cycling and climate. Limnology and Oceanography, 2009, 54(6), 2298-2314. http:// dx.doi.org/10.4319/lo.2009.54.6_part_2.2298.

VALDERRAMA, J.C. The simultaneous analysis of total and phosphorus in natural waters. Marine Chemistry, 1981, 10(2), 109-122. http://dx.doi. org/10.1016/0304-4203(81)90027-X.

WEISS, R.F. Carbon dioxide in water and seawater: the solubility of a non-ideal gas. Marine Chemistry, 1974 , 2(3), 203-215. http://dx.doi.org/10.1016/03044203(74)90015-2.

Received: 07 February 2017 Accepted: 07 August 2017 